\title{
Levinas i Husserl: transcendentalna intersubiektywność
}

DOI: http://dx.doi.org/10.12775/RF.2016.025

Zarówno w filozofii Levinasa jak i Husserla relacje między podmiotowe odgrywają istotną rolę w identyfikacji transcendentalnej podstawy. Według Edmunda Husserla obiektywność i transcendencja są konstytuowane przez transcendentalną intersubiektywność.

Każda dana typiczność zawiera się w topiczności totalności, należącej do całego nieskończonego horyzontu świata [...]. Horyzontalna świadomość, którą widzieliśmy już we wstępnej formie w łańcuchu prezentacji, posiada strukturę intelektualnych form i syntez, branych jako całość i w odniesieniu do swojej konstrukcji z indywidualnych percepcji, które są zależne podczas nadawania im sensu w swoim immanentnym byciu $^{1}$.

Wyjaśnienie takiej konstytucji wymaga jednak analizy doświadczenia drugiego podmiotu. Inny stanowi bowiem warunek możliwości doświadczenia świata, ponieważ obiektywność opiera się na transcendencji obcych podmiotów. Przedmiotów i zdarzeń doświadczamy zawsze jako czegoś publicznego, nie prywatnego, dlatego żaden podmiot nie może istnieć niezależnie od Innych. Ta ontologiczna analiza prowadzi do odsłonięcia innej subiektywności niż moja własna - do transcendentalnej intersubiektywności, która nie jest istniejącą strukturą w świecie.

Relacja między podmiotami może być analizowana wyłącznie z perspektywy pierwszoosobowej; tylko z perspektywy Ja transcendental-

1 Eugen Fink, Sixth Cartesian Mediatation, Indiana University Press, Bloomington 1995, s. 185. 
nego, gdzie wielość konstytuujących monad jest fenomenologicznie dostępna. To wskazuje na intersubiektywną strukturę ego oraz na egologiczne zakorzenienie intersubiektywności. W filozofii Levinasa kontakt z Twarzą Innego jest również interpretowany jako otwarcie się na transcendencję, która tutaj ma charakter etyczny². Kontakt z innymi monadami jest możliwy dzięki połączeniu ich w przestrzeni „an-archicznej” będącej przestrzenią należącą do absolutu. Według Levinasa tożsamość Ja jest niepokojona przez Innego, a Ja transcendentalne jest Ja czuwającym, gotowym nie tylko w każdej chwili zmienić perspektywę postrzegania siebie i świata, ale przede wszystkim zaświadczyć o tej absolutnej rzeczywistości. „Bezsenność czuwanie przebudzenia - niepokojona jest z głębi swej formalnej i kategorialnej jednakowości przez Inność, która rozbija to co w tej jednakowości zbija się w substancję Tego Samego, w tożsamość, w spoczynek, w obecność, w sen, który jednakowość osiąga" $^{\prime \prime}$. Czuwanie, o którym mówi Levinas jest nieintencjonalne. Analiza wewnętrznej świadomości czasu Husserla również dowodzi, że retencje i protencje nie ujawniają nowego przedmiotu intencjonalnego, lecz świadomość czasowego horyzontu przedmiotu4. Oznacza to, że absolutny obszar świadomości jest pasywnie obecny niezależnie od aktu uświadamiania go sobie. Analiza transcendentalnej intersubiektywności staje się zatem kluczem do zrozumienia konstytucji obiektywnej rzeczywistości, ponieważ przedmiot zostaje ukonstytuowany z mocą obowiązywania, która transcenduje podmiot. Moja indywidualna intencjonalność zawiera więc a priori odniesienie do transcendentalnej intersubiektywności jako transcendentalnego obszaru konstytucji. Dzięki temu doświadczam nie tylko transcendencji, ale też przejmuję od Innego obiektywizujące ujęcie mnie samego. To te przeżycia są podstawą do ukonstytuowania obiektywności. Absolut odkrywa siebie jako intersubiektywną relację między podmiotami ${ }^{5}$.

Pomimo że Levinas walczył z husserlowskim idealizmem, to jak twierdzi Marek Jędraszewski, istnieje wręcz organiczny związek Le-

2 Emmanuel Levinas, Bóg, śmierć i czas, Wydawnictwo Znak, Kraków 2008, s. 148

3 Emmanuel Levinas, O Bogu, który nawiedza myśl, Wydawnictwo Znak, Kraków 1994, s. 24.

4 Husserl wyróżnia czas świata doświadczania i immanentny czas upływu świadomości. Redukując spostrzeżenie przestrzeni do treści pierwszorzędnych tj. treści refleksji otrzymujemy kontinuum pola wizualnego, ale nie będącego żadną płaszczyzną w przestrzeni. „Odnajdujemy tutaj stosunki horyzontalnego i wertykalnego sąsiadowania, zawierania się, odnajdujemy również zamknięte linie całkowicie ograniczające jakąś część pola", w: Edmund Husserl, Wykłady z fenomenologii wewnętrznej świadomości czasu, Warszawa 1989, s. 10.

5 Podobnie uważają inni fenomenolodzy: Ludwig Landgrebe Der Weg der Phänomenologie, Gütersloher 1963, s. 191; Eugen Fink, Sixth Cartesian Meditation Indiana University Press 1995, s. 4-5, Anna T. Tymieniecka Życie w pełni logos, Poznań 2011, s. 181. 
vinasa z filozofią Husserla ${ }^{6}$. Główny zarzut Levinasa wobec Husserla dotyczył niemożliwości zastosowania metody fenomenologicznej w stosunku do Innego. Zarzucał on Husserlowi redukcję podmiotowości do czystej świadomości, przez co relacja z innymi Ja nabiera charakteru czysto teoretycznego. Czy rzeczywiście tak jest? Przeprowadzone badania przez Husserla i Finka nad transcendentalną subiektywnością pokazują że transcendentalizm (fenomenologizowanie) nie jest idealizmem, lecz systematycznie przeprowadzaną nauką egologiczną tj. odsłanianiem konstytuującej intencjonalności pomiędzy monadami. Początkowo transcendentalizm u Husserla jest statyczny, jednak później dochodzi do głosu genetyczna fenomenologia, przez co transcendencja daje się rozpoznać w doświadczeniu. Okazuje się, że nie tylko subiektywność ma swoje czasowe a priori, lecz rozwinięte subiektywne a priori odpowiada apriorycznej konstytucji genetycznej, która osadza się na tej pierwszej. Potwierdzają to także badania Quentina Lauera, który zauważa, że bardziej skomplikowane obiektywności nie mogły by być tworzone dopóki sama subiektywność nie będzie zdolna do bardziej skomplikowanych konstytucji. Dlatego subiektywność w fenomenologii musi być postrzegana równolegle do obiektywności ${ }^{7}$. U Levinasa na początku transcendentalizm jest empiryczny jednak później wskazuje on na pewne fenomeny, którym jest brak bezpośredniego związku z konkretnymi obiektami i ujawniają one związek $\mathrm{z}$ istnieniem jako takim. Są to takie fenomeny jak: znużenie, lenistwo, wysiłek, zmęczenie, zasypianie. Dokonując redukcji na tych fenomenach Levinas zauważa, że znużenie jest znużeniem samym soba, tj. niemożnością odrzucenia obowiązku istnienia. Lenistwo jako brak działania wobec istnienia jest strachem przed życiem. Zmęczenie z kolei ukazuje pewną sytuacje fundamentalną męczyć się to tyle, co męczyć siebie byciem. W zmęczeniu wyłania się istnienie tego, kto istnieje. Jak zauważa Jacek Migasiński: takie postępowanie pokazuje, że filozofia Levinasa jest pewną wersją fenomenologii ${ }^{8}$. Poprzez wprowadzenie Ilya Levinas stara się zrozumieć genezę podmiotu. Hipostaza w filozofii Levinasa jest nie tylko wydarzeniem, gdzie $\mathrm{w}$ istnieniu wyłania się ktoś istniejący kto ściąga na siebie swe istnienie. Narodziny hipostazy to narodziny świadomości. Materialna hipostaza według Levinasa pozostaje samotna, zamknięta w swej tożsamości. Wyjście poza tą tożsamość umożliwiają dopiero takie fenomeny jak: śmierć, kobiecość i płodzenie. Dlatego też epifania Twarzy w Jego

${ }^{6}$ Marek Jędraszewski, Wobec Innego. Relacje międzypodmiotowe w filozofii u Emmanuela Levinasa, Wydawnictwo Księgarnia Świętego Wojciecha, Poznań 1990, s. 176.

7 Lauer Quentin, The triumph of subjectivity, New York: Fordham University Press, 1978.

8 Jacek Migasiński, Transcendencja Levinasa, „Filo-Sofija” 2006, nr 1. 
filozofii nie jest światowym fenomenem, lecz wzywa ona do etycznego zachowania - zaświadczenia o absolutnej rzeczywistości.

W filozofii Levinasa Inny prezentuje absolutną rzeczywistość. Oddalenie od niej jest jednak tak radykalne, że nie można jej antycypować, a jedynie przeczuwać jej istnienie. Dlatego Inność może być transcendentalna tylko wtedy, gdy Ja jest punktem wyjścia dla tej relacji. Specyfika Ja polega na tym, że nie jest ono bytem, który pozostaje ciągle taki sam. Jego istnienie polega na odnajdywaniu swojej tożsamości we wszystkim co mu się przydarza. „Uniwersalna tożsamość, zdolna ogarnąć wszelką różnorodność, wspiera się na tożsamości podmiotu pierwszej osoby. Uniwersalna myśl to ja myślęe" . Według Levinasa relacja z Innym nie może być przedstawieniem, ponieważ Inny zawierał by się wówczas w Toż-Samym. Kontakt z Innym jest możliwy jedynie dzięki mowie, bo tylko wtedy Ja wychodzi poza siebie. Relacja Ja-Inny nie jest też całością należącą do bytu, jest to ruch ku transcendencji. Tej nieziemskiej relacji nie poznajemy inaczej niż poprzez urzeczywistnianie jej. Dlatego zarówno w filozofii Husserla jak i Levinasa absolut może się wydarzyć tylko poprzez Ja. Levinas podkreśla jednocześnie, że Inny pozostaje w Toż-Samym tylko w stosunku mowy, a to oznacza, że Ja nie może wymknąć się systemowi (historii), może to zrobić tylko Inny. Kim jest zatem Inny? Relacja z Innym to nowy wymiar świadomości, któremu dostępne jest to, co absolutne. Transcendencja nie jest więc czystą nicością bo w jakiś sposób istoczy się w świecie, tzn. byt może być zrozumiały, jeśli się go transcenduje odnosząc się do horyzontów, w których się ukazuje. Nie może to być tylko ruch w Toż-Samym, jak to jest w filozofii Heideggera. Relacja z transcendencją opiera się na separacji Ja, które o niej myśli tj. posiada idee nieskończoności w swoim umyśle. Wówczas odległość, jaka dzieli ideatum od idei nieskończoności, wyznacza treść samego ideatum. „Byt transcendentny jest jedynym ideatum, którego możemy mieć tylko ideę; jest od swej idei nieskończenie odległy - to znaczy zewnętrzny - ponieważ jest nieskończony"10. To dlatego pragnienie absolutu jest pragnieniem, które nie zaspakaja, a pobudza - jest pragnieniem bezinteresownej dobroci. To powoduje, że egoizm Ja zanika, co pozwala mu ofiarować posiadany sens świata Innemu. To dawanie dla samego dawania.

Relacja z Twarzą jest relacją ponad rzeczami, które stają się wspólne, ponieważ dają się wypowiedzieć - to relacja mowy. Zbliżyć się do Innego $\mathrm{w}$ rozmowie, to przyjąć jego ekspresję, która zawsze wykracza poza ideę zawartą w myśli. Przyjęcie Innego jest więc przyjęciem ponad zdolnością pojmowania Ja. W relacji z Nieskończonością wychodzimy

9 Emmanuel Levinas, Całość i Nieskończoność, Wydawnictwo PWN, Warszawa 2014, s. 22.

10 Ibidem, s. 39. 
od Ja, jednak prowadzi ona poza subiektywność. Z taką tezą zgadza się Husserl, ponieważ według niego sens tworzony jest na nowo w oparciu o to, co wychodzi od Innego ${ }^{11}$. Na poziomie doświadczenia społecznego oznacza to konieczność uwzględnienia intersubiektywności, która według fenomenologii jest podstawą dla konstytucji. Co zatem z życiem wewnętrznym monady? Jak twierdzi Levinas, życie wewnętrzne jest jedynym sposobem, w jaki rzeczywistość może istnieć jako wielość. Pomimo że monady są różne, to są tego samego rodzaju, tj. w myśleniu tworzą całość. Rozmowa zakłada wielość, która wynika z wewnętrznego odnoszenia się do siebie samego. Modusem stawania się jest więc wielość czujących bytów, a transcendencja czy też absolut ujawnia się $\mathrm{w}$ stosunkach etycznych pomiędzy monadami. A zatem warunkiem tego, by posiadać ideę Nieskończoności, jest istnienie jako byt odseparowany, ponieważ to uniemożliwia jej totalizację poprzez nieskończoność drugiego człowieka.

Zarówno w filozofii Husserla, jak i Levinasa transcendencja daje się zauważyć jedynie w horyzontach bytu. Levinas zauważa, że widzenie rzeczy zakłada światło, którego oko może nie widzieć, bo widzi tylko rzecz w świetle ${ }^{12}$. Husserl również porównuje świadomość do światła. Czy zatem światło jest początkiem świadomości? W relacji ze światłem Levinas upatruje metaforę wszelkiej relacji z absolutem. Taka świadomość wymaga jednak poznania o nowej strukturze. Podobnie jak Edyta Stein, Levinas uważa, że przyjęcie absolutu nie przekreśla indywiduum, nie neguje Toż-Samego ${ }^{13}$. Absolut zostaje przyjęty na miarę tego, kto go przyjmuje. Levinas twierdzi, że ten, kto przyjmuje ideę Nieskończności, staje się bytem nauczanym i wychodzi poza siebie. Myśleć to znaczy być

11 Husserl wyróżnia auto konstytucję ego, w której ego konstytuuje się dla samego siebie. Konstytucja ta prowadzi dalej do uniwersalnej jedności konstytucji utrzymującej się w moim ego, której korelatem jest obiektywnie istniejący świat, który „kształtuje się dalej we (wciąż nowych) warstwach sensu, rozwijając się przy tym jednak w odpowiednim apriorycznym stylu. I ten rodzaj konstytucji jest sam czymś ze sfery a priori" (Edmund Husserl, Medytacje Kartezjańskie, Wydawnictwo PWN, Warszawa 1982, s. 205).

12 Tymieniecka zauważa, że indywiduum jest uważane za reprezentanta życia-w-toku, ponieważ na jego podstawie daje się wyróżnić konstruktywne procesy, postęp, sprzyjające i niesprzyjające warunki oraz samo dokonanie się. Indywiduum samo pobudza się do istnienia przez co daje się ono przyrównać do absolutu. „W grze swych zarodkowych, ukierunkowanych i pobudzających energii i sił, płynnie współdziałających z zależnościami i zmiennymi warunkami, chociaż ucieleśniony, samoindywidualizujący się podmiot uniezależnia się jako nośnik odwiecznego światła" (Anna T. Tymieniecka, Życie..., op. cit., s. 96. ).

13 „Od istnienia boskiego dzieli je oczywiście nieskończony dystans, a mimo to podobne jest do niego bardziej niż cokolwiek innego, co leży zasięgu naszego doświadczenia: właśnie przez to, że jest ono Ja, że jest osobą" (Edyta Stein, Byt skończony a byt wieczny, Wydawnictwo Ojców Karmelitów Bosych, Kraków 1995, s. 360). 
nauczanym. Nieskończony absolut sam wyznacza granice pojęć, przez co nie może być zdefiniowany. Dlatego epifania Twarzy nie daje się ukonstytuować jak inne byty, bo ujawnia ona Nieskończoność. Jednak czy człowiek może uznać coś, co jest nie ukonstytuowane w świadomości? Levinas pisze:

[...] niewyczerpany nadmiar nieskończoności wylewa się poza każdą aktualną świadomość. To wylewanie się Nieskończoności, czyli twarz, nie daje się wypowiedzieć w terminach aktów świadomych, w metaforyce światła i rzeczywistości zmysłowej. Etyczny wymóg twarzy kwestionuje świadomość, która ją przyjmuje. Świadomość zobowiązania nie jest już świadomością, bo wyrywa świadomość z jej centralnego położenia i podporządkowuje ją Innemu... Rozum pojęty jako bezosobowe prawo nie pozwala wytłumaczyć (roz)mowy, bo wchłania i likwiduje wielość rozmówców. Rozum, będąc czymś jedynym, nie może rozmawiać z innym rozumem ${ }^{14}$.

Słowa te mogą świadczyć o tym, że Levinas kwestionuje Ja w nastawieniu naturalnym, ale nie świadomość jako taką. Świadomość Ja zostaje wyrwana z naturalnego świata przez Innego i włączona w uniwersum transcendentalnej intersubiektywności, która nie jest już światowym obiektem. Jeżeli nieskończony Rozum przekracza każdą aktualną świadomość, to nieskończoność, o której mówi Levinas odnosić się może do uniwersalnej świadomości, której akty mogą być spełniane przez wszystkie monady ${ }^{15}$. Uniwersalna świadomość nie zanika, lecz przemieszcza się pomiędzy Twarzami. Inny nie unicestwia mojej świadomości, lecz anuluje mój egoizm i przemienia moje widzenie świata. Wszystko zatem dzieje się w jednej absolutnej świadomości. To dzięki niej fenomeny mogą prowadzić do jednego tego samego sensu. Należy więc pominąc intencjonalność $\mathrm{w}$ poznaniu uniwersalnego porządku i wystąpić przeciw psychologizmowi, tak jak chciał tego Husserl. Wówczas jednostkowa świadomość wycofałaby się do sfery horyzontalnej, gdzie bezczasowo spełniałaby rolę absolutnego podmiotu, który zakłada pluralizm relacji społecznych. Pomimo że podstawą obiektywności jest proces subiektywny, to obiektywność nie dotyczy jednego podmiotu, lecz relacji z Innymi - obiektywizacja jest dziełem mowy, która przedstawia transcendentalny byt. „Mowa spełnia taką relację między członami, że rozrywają one jedność rodzaju. Te człony, czyli rozmówcy uwalniają się relacji, to znaczy pozostają w niej absolutne. Mowę moż-

14 Emmanuel Levinas, ibidem, s. 245.

15 Transcendentalna fenomenologia prowadzi do uniwersalnej samowiedzy początkowo wewnątrz monady, a potem pomiędzy monadami. Clark Moustakas, Fenomenologiczne metody badań, Wydawnictwo Uniwersyteckie Białystok, Białystok 2001, s. $28-41$. 
na chyba zdefiniować jako zdolność rozrywania ciągłości bytu lub historii"16. Mowa nie jest tylko rodzajem aktywności. Język jest możliwy, jeżeli słowo nie spełnia funkcji aktu i powraca do swojej istoty jaką jest sama ekspresja. Levinas uważa, że mowa wychodzi poza immanencję. Mowa nie rozgrywa się wewnątrz mojej świadomości, lecz przychodzi z zewnątrz od Innego. Twarz nie daje się sprowadzić do Toż-Samego, w związku z czym w relacji pozostaje ona absolutna, kwestionując zdolność pojmowania mojego Ja. Dzięki temu przedmiot transcendentalny może zaskakiwać myśl. Istota języka nie tkwi w cielesnej operacji, jego podstawa tkwi w uobecnianiu się sensu.

Różnica pomiędzy Levinasem a Husserlem w rozumieniu czystej świadomości polega na tym, że Levinas utożsamia czystą świadomość ze świadomością teoretyczną i dlatego według niego znaczenie bycia polega na kwestionowaniu transcendentalnej konstytucji przez etyczną relację. „Znaczenie to Nieskończoność, a Nieskończność nie ukazuje się transcendentalnemu myśleniu ani nawet sensownemu działaniu, lecz uobecnia się w Innym"17. Relacji tej nie można dodać do wewnętrznego monologu. Badania Husserla i Finka nad czystą świadomością pokazują jednak, że nie jest to stała struktura zamknięta w immanencji. Cechuje ją przede wszystkim to, że ona ciągle się poszerza, zagarniając coraz to nowe obszary bytu ${ }^{18}$. Moje ego po dokonaniu redukcji przechodzi transformację, gdyż zaczyna widzieć siebie jako monadę - ontyczny fenomen w świecie i zaczyna opierać swoje myślenie nie na sobie, lecz wraz z innymi monadami przynależy już do wspólnej rzeczywistości jaką jest transcendentalna intersubiektywność. Wspólne dla Husserla i Levinasa jest jednak to, że transcendentalna subiektywność i Nieskończoność nie dają się zamknąć w pojęciach. Główny zarzut Levinasa wobec Husserla dotyczy tego, że nawet idea Nieskończoności musi być ukonstytuowana przez czystą świadomość. Konstytucja u Husserla to proces, który rozwija się w obrębie struktury podmiotowość-świat. Nie jest to dedukcja świata z pozaświatowego podmiotu czy redukcja do tego podmiotu. Transcendentalne bycie jako konstytuujące charakteryzuje się pewnym schematem transcendentalnym podmiot-świat w ramach, którego

16 Emmanuel Levinas, ibidem, s. 228.

17 Emmanuel Levinas, ibidem, s. 244.

18 Absolut nie może być rozumiany za pomocą aperceptywnych schematów skończonej kognicji. Samokognicja absolutu jest transcendentalną analogią. Jest to analogia pomiędzy skończonym refleksyjnym poznaniem (psychicznym autodoświadczaniem) i nieskończoną absolutną autokognicją. Absolut $\mathrm{w}$ tym sensie nie jest konstytucją świata, lecz jest to jedność transcendentalnej konstytucji z transcendentalnym procesem fenomenologizowania. Eugen Fink, Sixth Cartesian Meditation, Indiana University Press 1995, s. 151. 
mogą zjawiać się podmioty ${ }^{19}$. Absolut nie należy do świata, a jego istotą jest przecież tworzenie; „,[...] jego absolutność polega na ab-solucji lub otrzeźwieniu, na przebudzeniu i na utrzymywaniu się w bezsenności, gdyż zredukowaną rzeczywistość poddajemy dalszym redukcjom, rozbijając resztki dogmatyzmu"20.Jedyna konstytucja o jakiej tutaj można mówić, to konstytucja samego stawania się, która nie może być raz na zawsze określona. Fenomenologiczna redukcja naprowadza Levinasa na tą samą intuicję:

Wola jeśli w taki czy inny sposób zmierza do rozumu, jest już rozumem, rozumem szukającym się lub się tworzącym... Totalna refleksja jest niemożliwa ze względu na nadwyżkę relacji społecznej, gdy subiektywność staje w obliczu innego bytu, przyjmuje go z prostotą i nie daje się zmierzyć miarą prawdy ${ }^{21}$.

Odpowiedź na byt absolutny musi mieć więc charakter osobowy, a warunkiem prawdy jest podmiotowość i jej płodność. Jeżeli mówimy o byciu jako stawaniu się to musimy uznać byt, który jest poza Jestestwem. $Z$ analiz Husserla i Levinasa wynika, że aktświadomości posiada swoją dynamikę, która znacznie go wyprzedza. W jaki sposób można zatem utrzymać jednocześnie Ja i transcendencję? Levinas zauważa możliwość koegzystencji obu członów odwołując się do pędu życiowego, który anuluje separację jednostek poprzez seksualność, która tutaj przestaje być jedynie czystą przyjemnością i staje się pewną nieredukowalną kategorią. Poprzez akt seksualny podmiot wchodzi w relację z transcendencją Innego - z Twarza, która wymyka się logice formalnej. Płodzenie u Levinasa zostaje podniesione do rangi ontologicznej. Jest to taki rodzaj transcendencji, w której nośnikiem nie jest już Ja, lecz ,ja jestem", które jest obecne w każdym pokoleniu. Płodzenie jako kategoria ontologiczna jest transcendencją Ja, ponieważ znacznie wykracza poza biologiczną empirię. $W$ tak rozumianej transcendencji Ja wyzwala się od siebie nie przestając być sobą bo Ja zostaje zachowane w spłodzonej nowej istocie. Płodzenie jest bowiem taką dialektyczną struktura, która zachowuje dwa sprzeczne ruchy. A zatem kreacja jako relacja transcendencji jest warunkiem powstania indywiduum. Ja może zaistnieć tylko pod warunkiem, że zwraca się w stronę Twarzy Innego. Być nieskończenie dla Levinasa oznacza istnieć bez granic, tzn. być źródłem - ciągłym rozpoczynaniem na nowo. Bez źródła, jakim jest Ja, nieskończone istnienie było by niemożliwe. Ja pozostaje w bycie i jednocześnie się dy-

19 Dan Zahavi, Fenomenologia Husserla, Wydawnictwo WAM, Kraków 2012, s. 98-105.

20 Emmanuel Levinas, Istniejący $i$ istnienie, Wydawnictwo Homini, Kraków 2006, s. 79 .

${ }^{21}$ Emmanuel Levinas, Całość..., op. cit., s. 259 oraz s. 263. 
stansuje wobec niego ${ }^{22}$. Ten dystans wobec bytu sprawia, że Jestestwo może widzieć prawdę, tj. transcendentalne uwarunkowania konstytucji. Jest to antycypacja w nieskończonych możliwościach, gdzie byt może pozostać w zawieszeniu i w każdej chwili może rozpocząć coś nowego. Struktura świadomości jest więc naznaczona przez byt, który odmawia totalizacji23.

Dystans wobec świata osiągany w płodzeniu nie dotyczy tylko świata, ale też aktu aktualnej świadomości, która wybiera dla siebie możliwości. Dzięki płodzeniu dysponuję nieskończonym czasem, którego konstytucja jest nienaruszalna. Jest to warunek dla wypowiadania prawdy o bycie. Oznacza to, że transcendentalna intersubiektywność nie jest czymś z góry założonym.

Krzywizna intersubiektywnej przestrzeni sprawia, że odległość ukazuje się jako wysokość, co nie fałszuje bytu, lecz umożliwia prawdę... Ta przewaga prawdy nad bytem i jego idea, przewaga, którą sugeruje metafora krzywizny intersubiektywnej przestrzeni, oznacza boską intencję wszelkiej prawdy. Ta krzywizna przestrzeni jest może obecnością samego Boga ${ }^{24}$.

Zarówno idea Nieskończoności, jak i opis relacji społecznych, nie daje się sprowadzić do logiki formalnej. Nieskończoność sprowadza się tu do logiki wewnętrzności Ja co sugeruje, że może łączyć się ono z czymś co jest poza Nim. Implikuje to możliwość istnienia korzeni świadomości wolnego Ja w absolutnej świadomości, która będąc warunkiem tworzenia świata może być nieskończona. Ta wcześniejsza ode mnie przestrzeń stanowi matrycę, z której ontologiczna filozofia wyprowadza byty ${ }^{25}$.

Według Levinasa absolut łączy w przestrzeni "an-archicznej” wszystkie Ja i dzięki temu Inny może być Jego obrazem - „śladem abso-

22 Jestestwo samotranscenduje się, jest samą otwartością. Dlatego należy określić konstytucję takiego bycia. Martin Heidegger, Bycie i czas, Wydawnictwo PWN, Warszawa 1994, s. 189.

${ }^{23}$ Jak zauważa Ludwig Landgrebe Husserlowi również brakowało pojęć do określenia Ja transcendentanego, ponieważ jako absolutna wolność i otwartość na absolutne doświadczanie wyklucza ono zastosowanie wobec siebie pojęcia bytu jako stałej przedmiotowości; stoi w opozycji do idealistycznego pojęcia absolutnego bytu. Ludwig Landgrebe, Der Weg der Phänomenologie, Gütersloh 1963, s. 18-19. Podobne wnioski wysuwa Maciejczak; Ja nie może być sumą minionych cogitationes, żadnym przedmiotem i aktualną samo obecnością. Ja ulega rozszczepieniu dzięki czemu ustala się najogólniejsza struktura świadomości: ego-cogito-cogitatum. To dlatego świadomość nie jest sama dla siebie przejrzysta. Oscyluje pomiędzy odniesieniem do świata, a do samej siebie - to doświadczenie własnej sprawczości. Marek Maciejczak, Czasowość i jedność świadomości Kant-Husserl-Merleau-Ponty, „Principia” 2007, T47/48, s. $132-133$.

24 Emmanuel Levinas, ibidem, s. 348-349.

25 Edmund Husserl, Badania logiczne, Wydawnictwo Comer, Toruń 1996, t. 1, s. 34. 
lutu". Transcendencja nie daje się zamknąć w całość; różne Ja nie tworzą w Tym-Samym całości, a jednak wszystkie Ja łączy wspólna zasada jaką jest Twarz i mowa, które wyrażają Prawdę niedającą się wywieść z mojego wnętrza. Levinas modyfikuje źródłowy sens prawdy i struktury noetyczno-noematycznej uznawanej za sens intencjonalności. To pokazuje, że o absolucie można mówić poza teologią. Pomimo że Twarz zachowuje dystans i zawsze wychodzi poza immanencję, to jednak jest ona obecna w świecie; absolutna świadomość musi być w jakiś sposób obecna w świecie ${ }^{26}$. Rozmowa z Innym byłaby wtedy rozmową z absolutem. Istnienie bytu oddzielonego od zewnętrzności nie polega więc na trosce o bycie; egzystencja ma inny sens niż trwanie w całości. Trwanie staje się widoczne w relacji z Innym, bo tylko w niej byt może przekraczać siebie. Oznacza to, że transcendencja jest zawsze transcendencją Ja - jedynego bytu gotowego na to, by odpowiedzieć na wezwanie absolutu.

Transcendentalna intersubiektywność stanowi punkt kulminacyjny w badaniach Edmunda Husserla. Jej znaczenie zaczyna on nakreślać dopiero w swoich końcowych pracach. Husserl podkreśla fakt, że rozpoczynając fenomenologizowanie zawsze rozpoczynamy jako solipsysta, ponieważ najpierw dokonujemy redukcji primordialnej tzn. wyodrębniamy to, co zostało ukonstytuowane w moim wnętrzu bez udziału innych podmiotów. Paradoksalnie punktem wyjścia w badaniach Husserla nad transcendentalną intersubiektywnością nie jest podmiot jak u Levinasa, lecz sposób prezentacji danej dziedziny ontologicznej dzięki czemu inne podmioty nie mogą być doświadczane subiektywnie. Przedmioty danej dziedziny prowadzą bowiem do struktur przeżyciowych i intencjonalnych wszystkich podmiotów. Redukcja transcendentalna prowadzi do istotowo określonej struktury zacieśniającej pole uniwersalnej konstytucji. Oznacza to, że najpierw dokonuję apercepcji siebie samego, która przebiega $\mathrm{w}$ określonych konstytuujących przebiegach nadających apercepcji charakter czegoś o trwałym statusie obowiązywania. Potem, odkrywając tą osadzającą się w świecie apercepcję, mam możliwość powrotu do siebie samego jako Ja transcendentalne. Apercepcja świata staje się wtedy czymś wtórnym, a Ja transcendentalne odkrywa swoją immanentną czasowość przeżyciową różną od czasu liniowego. Ta ontologiczna analiza prowadzi do odsłonięcia innej subiektywności niż moja własna. Prowadzi ona do transcendentalnej intersubiektywności, która dla Husserla jest źródłem prawdy i bytu. Transcendencja, obiektywność i realność są konstytuowane intersubiektywnie, tzn. mogą być ukonstytuowane tylko przez podmiot, który doświadcza innych podmiotów. Fenomenologizowanie wymusza więc przejście od egologicznej do

26 Ingarden przyznaje, że tylko pogląd o istnieniu czystej świadomości jako podstawy gwarantuje bezwzględną pewność wyników poznawczych. Roman Ingarden, Spór o istnienie świata, Wydawnictwo PWN, Warszawa 1987, t. 2, s. 260. 
transcendentalno-socjologicznej fenomenologii, do której pierwszym krokiem jest redukcja primordialna. Husserlowi nie chodzi tu jednak o badanie relacji Ja-Ty, tylko o wczucie. Jest to pytanie o to, w jaki sposób mogę doświadczać drugiego podmiotu ${ }^{27}$. Husserlowska teoria wczucia zakłada podobieństwo w strukturach noetyczno-noematycznych wszystkich podmiotów. Nie jest to wnioskowanie przez analogię. Chodzi raczej o odsłonięcie warunków możliwości empatii. Inny doświadczany jest inaczej niż zwykłe przedmioty. To dzięki niedostępności Innego można mówić o relacji podmiot-podmiot. Wspólne wnioski, do jakich dochodzą tu Husserl i Levinas, dotyczą znaczenia intersubiektywności $\mathrm{w}$ samokonstytucji Ja transcendentalnego, tj. żaden podmiot nie może istnieć niezależnie od Innych ${ }^{28}$. Moje doświadczenie Innego może być halucynacja, ale konstytutywny związek między intersubiektywnością a obiektywnością musi być aprioryczny. Obiektywność spoczywa więc na transcendencji obcych podmiotów (moje doświadczenie zmienia się kiedy pojawia się drugi podmiot); przedmiotów nie można redukować jedynie do własnych intencjonalności. To, że przedmiot doświadczany jest intersubiektywnie, gwarantuje jego transcendencję, tzn. przedmiot zostaje ukonstytuowany $\mathrm{z}$ mocą obowiązywania, która transcenduje sam podmiot, przez co zostaje mu nadana autonomia przekraczająca moją skończoną egzystencję. W ten sposób dochodzę do zrozumienia, że istnieje różnica pomiędzy rzeczą $\mathrm{w}$ sobie a zjawiskiem dla mnie. Każdy przedmiot zakłada bowiem odniesienie do Innych; przedmioty odznaczają się horyzontalnym sposobem prezentacji. Stąd Husserl i Levinas wyprowadzają wniosek, że moja intencjonalność zawiera a priori odniesienie do „otwartej intersubiektywności”, którą odsłania wczucie w Innego. Dzięki Innemu mogę doświadczać siebie jako alter ego obcych podmiotów, a to pociąga za sobą zmianę w postrzeganiu własnej konstytutywnej roli. Jest to monadologia, do której odwołuje się zarówno

27 Wczucie nie ma charakteru spostrzeżenia zewnętrznego. We wczuciu drugi człowiek nie jest obiektem, lecz w nim zwracam się ku jego obiektowi. Akt jaki temu towarzyszy polega na tym, że pomimo iż nie doświadczam źródłowo tego co inny podmiot to jestem prowadzony przez przeżywanie źródłowe dające się rozpoznać w moim nie źródłowym doświadczeniu. Wszyscy bowiem dysponujemy tymi samymi noetyczno-noematycznymi systemami. Dlatego z Ja i Ty wyrasta My jako podmiot wyższego rzędu. Edyta Stein, O zagadnieniu wczucia, Wydawnictwo Znak, Kraków 1988, s. 33.

28 Według Landgrebego absolutny byt to uniwersum transcendentalnych podmiotów; transcendentalne Wszech-Ja. Solipsyzm jest jedynie etapem metodycznym, ponieważ jeżeli pytamy o prawdę wszystkiego istniejącego według kryterium samo-jestestwa i jeżeli inny nie oprze się temu egologicznemu kryterium to jest to dowód na istnienie transcendencji w stosunku do własnego subiektywnego związku, która ma własny sposób wykazania się w utrzymaniu się apercepcji „innych" w przebiegu doświadczenia. Ludwig Landgrebe, Der Weg der Phänomenologie, Gütersloh 1963, s. 191. 
Husserl, jak i Levinas. Jestem świadomy, że istnieje różnorodność czujących Ja, i że doświadczenie każdego Ja ma tą samą moc obowiązywania. Transcendentalna intersubiektywność nie może być więc obiektywnie istniejącą strukturą w świecie. Jest to relacja między podmiotami, która może być analizowana wyłącznie z perspektywy pierwszoosobowej ${ }^{29}$. Dylemat dotyczący pierwszeństwa pomiędzy Ja transcendentalnym a transcendentalną intersubiektywnością zanika, ponieważ miejscem gdzie ujawnia się intersubiektywność może być jedynie relacją między dwoma indywiduami. To pokazuje, że teoria subiektywności nie jest nieegeologiczna. Gdyby była nieegologiczna, to byłby to problem wyłącznie empiryczny. A tak nie jest.

Według Husserla oczywistość może być bardziej lub mniej doskonała. Dlatego nie należy przyjmować niczego, co nie byłoby zaczerpnięte ze sfery, która daje nam absolutną pewność. Taką apodyktyczną oczywistością jest ta, która ma oparcie $\mathrm{w}$ Ja myślącym zradykalizowanym poprzez redukcję epoche, która pozwala uchwycić mnie jako czyste Ja- monadę. Po redukcji czyste Ja postrzega siebie wraz ze swym nieokreślonym horyzontem. Ten nieokreślony horyzont oznacza, że odsłonięta transcendentalna subiektywność jest transcendentalną intersubiektywnością. Aby odkryć co kryje się w tym horyzoncie potrzebna jest wspomniana już wcześniej redukcja primordialna, która pokazuje jak doszło do konstytucji innych Ja. Transcendentalne Ja uświadamia sobie wówczas co znaczy, że stało się człowieczo osobowym Ja czyli, że transcendentalno-intersubiektywna wspólnota również doznała tego uświadomienia. Pojęcie monady odgrywa istotną rolę w filozofii Husserla. Pojęcie to umożliwia wytłumaczenie powiązania teorii intencjonalności $\mathrm{z}$ teorią konstytucji czasu. Transcendentalny czas wspólnoty monad nie jest ostatecznym transcendentnym czasem i dlatego Husserl wprowadza pojęcie pozaczasowego źródła wszelkiego czasu, którym jest pozaczasowa subiektywność rozpadająca się na Ja monadyczne ${ }^{30}$. Konstytucja Innego jest więc rezultatem pluralizacji monadycznej pierwszej subiektywności. Mamy więc Ja jako biegun aktów i Ja jako substrat określeń habitualnych, tzn. dokonując refleksji na swoich przeżyciach natrafiam

29 Absolutna świadomość i Ja transcendentalne nie muszą się ze sobą utożsamiać. "Pomimo to jednak nie da się zaprzeczyć, że świadomość przejawia zarówno strukturę egologiczną jak i podmiotową (jest świadomością podmiotu)... moje skupienie uwagi wskazuje na ja, które jest (jest moje). W ten sposób chwytam jednocześnie jego swoistą indywidualność. Jak się zdaje nie polega ona na tym, że ja jest nacechowane ostatecznymi odmianami konkretnych jakości, jak przedmiot przestrzenno-czasowy, ale po prostu na tym, że nie jest to ono ja kogoś innego pomimo i wbrew jakiemukolwiek jakościowemu ukwalifikowaniu" (Józef Tischner, Ja transcendentalne w filozofii Edmunda Husserla, doktorat, Kraków 1963, s. 97-98).

30 Stanisław Judycki, Intersubiektywność i czas, Towarzystwo Naukowe KUL, Lublin 1990, s. 126-131. 
na pewne dające się ująć opisowo i rozwinąć intencjonalnie typy i trzymając się odsłaniających się ich ejdetycznych horyzontów postępować dalej w operacji intencjonalnego odsłaniania zawartości mojej własnej monady ${ }^{31}$. W ten sposób uwalniam swoje spostrzeżenia $\mathrm{z}$ faktyczności i zajmuję się ich ejdetycznymi możliwościami. Akt uzmienniania musi być aktem zapewniającym oczywistość, musi być zachowana istotowa ważność. Ostatecznym celem fenomenologii transcendentalnej jest zatem określenie ejdosu Ja transcendentalnego, które będzie odnosić się do wszystkich monad. To prowadzi do absolutnej fenomenologii transcendentalnego Ja, nieposiadającej już żadnego horyzontu prowadzącego poza sferę transcendentalnego bytu.

Na czym więc polega absolutność transcendentalnego bytu? Husserl w Medytacjach pisze:

Uniwersalne priori, które określa ego transcendentalne jako takie, jest istotnościową formą zawierającą w sobie nieskończoność innych form, apriorycznych typów możliwego, aktualnego i potencjalnego życia wraz z konstytuującymi się w nim jako coś rzeczywiście istniejącego ${ }^{32}$.

W konstytucji ego zawarte są wszystkie procesy wszystkich istniejących dla niego przedmiotów immanentnych, transcendentnych, idealnych i realnych. W jedności uniwersalnej genezy znajdują się różne formy ukonstytuowanych przedmiotów, między którymi daje się odnaleźć trwała ontologiczna struktura - uniwersum. Systemy konstytutywne aktualizowane przez ego są możliwe jedynie w ramach genezy posiadającej charakter prawa. Są one również związane pewną formą genetyczna, która czyni możliwym istnienie konkretnego ego (monady) jako jedności harmonijnie spójnych zasobów bytowych. W ten sposób Husserl przekonuje, że jedynie fenomenologia genetyczna może poddać genezie ego i wydobyć z niego aprioryczne formy ${ }^{33}$. Po transcendental-

31 Habitualności wyznaczają style poznawcze przedmiotów. Dzięki temu każdy przedmiot odsyła do swojego prawidła struktury, według którego może być dany innym odmianom świadomości w swojej typice. Gdyby świadomości sądu nie towarzyszyła przedrefleksyjna samoświadomość, nie można by skierować uwagi na sam proces poznania. Dzięki habitualnościom to co ukonstytuowane ma trwałą ważność jako idealnej obiektywności dla wspólnoty poznawczej. Marek Maciejczak, Rola stosunków aktywność-pasywność w husserlowskiej teorii świadomości, „Kwartalnik Filozoficzny", t. 42, z. 3, s. 39.

32 Edmund Husserl, Medytacje Kartezjańskie, Wydawnictwo PWN, Warszawa 1982, s. 108.

33 Różnica pomiędzy fenomenologią genetyczną i statyczną polega na tym, że ta pierwsza zajmuje się badaniem konstytutywnych podstaw życia, które są zasugerowane $\mathrm{w}$ teraźniejszości. Zaś fenomenologia statyczna zajmuje się konstytutywną analiza przepływu doświadczenia. Eugen Fink, Sixth Cartesian Meditation, Indiana University Press 1995, s. 6. 
nej redukcji na własnym ego zauważamy pewne ego w ogóle, które dysponuje poprzez akty świadomości już pewnym gotowym światem. Poprzez odsłonięcie form, jakie przybierają prawa przynależącej tu genezy, można uchwycić fenomenologię ejdetyczną jako spójną całość. W niej ego uzmiennia się tak swobodnie, że nie wymaga to już ukonstytuowanego dla niego świata. W jaki sposób jednak to co w mojej świadomości pojawia się jako oczywiste może mieć znaczenie obiektywne? Według Husserla uchwycenie transcendencji jest możliwe jedynie dzięki redukcji fenomenologicznej na życiu świadomości. Odkrywam wtedy, że to co istnieje dla ego, jest czymś, co się w nim samym konstytuuje „„...] transcendencja jest $\mathrm{w}$ każdej ze swych postaci immanentnym konstytuującym się w obrębie ego charakterem bytowym" ${ }^{\prime 34}$. Każdy wtedy dający się pomyśleć sens przynależy do transcendentalnej subiektywności. To, co znajduje się poza nią, jest według Husserla nonsensem. Zadaniem każdego Ja transcendentalnego jest więc aprioryczne wydobywanie faktów z własnej świadomości i umieszczanie ich w uniwersum czystych możliwości. Uniwersum możliwości, którymi Ja sam dysponuję jako ego transcendentalne.

Transcendencja w filozofii Levinasa i Husserla daje się rozpoznać jedynie jako relacja osobowa; wielość transcendentalnych egos wskazuje na jedyny egocentryczny sposób dania mojej świadomości. Tylko Ja może samo prezentować się sobie i doświadczać wewnętrznej świadomości czasu. Jednocześnie, tylko takie Ja może uznać równoczesność istnienia wielu transcendentalnych egos $\mathrm{w}$ świecie. Transcendentalne Ja to nie ego w rozumieniu kantowskim, bo nie jest ono tak odizolowane od świata. W przypadku Husserla mamy do czynienia z systematycznymi wyjaśnieniami zawartości Ja transcendentalnego, gdzie ujawniane są horyzonty, które współokreślają sens bytowy i posiadają dla ego moc obowiązującą jako coś obiektywnego. Inaczej rzecz ma się w przypadku Levinasa - tutaj relacja z transcendencja, czyli z Innym nie daje się zamknać $\mathrm{w}$ sensowych pojęciach. $\mathrm{W}$ obu przypadkach mamy jednak do czynienia z obiektywnościa która jest tworzona w oparciu o pewną transcendencję. Według Levinasa dzięki Innemu doświadczam nie tylko transcendencji, ale też przejmuję od niego obiektywizujące ujęcie mnie samego. To te przeżycia $\mathrm{w}$ obu przypadkach są podstawą do ukonstytuowania prawdziwej obiektywnej rzeczywistości. Zarówno Husserl, jak i Levinas, dokonując analizy subiektywności dochodzą do wniosku, że od zawsze obecny jest w niej Inny, tj. od kiedy sięgnąć pamięcią żyjemy wśród ludzi i moje antycypacje są skorelowane z intersubiektywnie przekazywanymi formami apercepcji. Istnieje więc korelacja między różnymi obiektywnościami, tzn. wszystko jest skorelowane z rozumnością podmiotów. Dowodem na to jest proces nieustannej ko-

34 Edmund Husserl, Medytacje..., op. cit., s. 122. 
rekty w świecie. Istnienie świata tylko z pozoru jest stabilne, w każdej chwili może bowiem rozpaść się stworzona konstrukcja obiektywności. Husserl i Levinas zgadzają się, że dopiero pokoleniowa intersubiektywność dowodzi, iż narodziny, śmierć i płodność są transcendentalnymi warunkami możliwości konstytucji świata. Podmiot jest mimowolnie zanurzony $\mathrm{w}$ tej z początku anonimowej transcendentalnej intersubiektywności. Problem polega na tym, że Inne ego we mnie nie jest syntetyczną jednostką możliwą do potwierdzenia w moim wnętrzu przez co problem Innego nie może być całkowicie przedstawiony fenomenologicznie. Konieczny jest zatem wgląd w rozwiniętą intencjonalność i odpowiedź na pytanie w jakich systemach motywacji kształtuje się sens Innego? Zagłębiając się w treść noematyczno-ontologiczną Innego można zauważyć, że jest on odpowiednikiem mojego Cogito, którego strukturę trzeba dopiero odsłonićs ${ }^{35}$. To w obrębie mnie samego, w ramach czystego życia świadomości doświadczam świata wraz z istniejącymi w nim Innymi. Każdy jednak posiada swój fenomen świata, mimo że doświadczany świat jest czymś co istnieje w sobie i jest przedstawiany wszystkim doświadczającym go podmiotom i ich fenomenom świata ${ }^{36}$. U Husserla to teoria wczucia stanowi fundament dla tak rozumianej transcendental-

35 Jak uważa Quentin Lauer Husserl w Ideach rozwija korelatywną strukturę aktu intencjonalnego. Subiektywna struktura aktu określona jako noezis jest zamiennie stosowana z obiektywną strukturą zwaną noemą. Nie są to dwa odmienne komponenty aktu. Oznacza to raczej, że jeden akt posiada podwójną strukturę; jedną realną, drugą intencjonalną przez co akt może być analizowany na dwa sposoby. Noezis jest intencjonalnym aktem patrzenia na coś jako realnie subiektywne działanie. Zaś noema to ten sam akt patrzenia na coś jako posiadający intencjonalną strukturę. Poddając wtedy akt refleksji można zauważyć serię obiektywnych modalności odnoszących się do danego aktu. Każdej subiektywnej modalności odpowiada zatem obiektywna modalność, a badanie subiektywnych modalności aktu w coraz większym stopniu ujawnia obiekt. Lauer Quentin, The triumph of subjectivity, New York: Fordham University Press 1978, s. 93-96.

36 Przedmiotem spostrzeżenia immanentnego nie są przeżycia istot żywych należących do świata przyrody, lecz przeżycia jako fenomeny samo prezentujące się. To, co jest dane w takim spostrzeżeniu, jest absolutne. „Ponieważ istota świadomości naturalnej polega na tym, że odnosi się ona do wstępnie danego świata, świadomość, jeśli ujmuje to, co wstępnie dane, jako rezultat uznania $w$ bycie, nie jest już sama świadomością naturalna, lecz transcendentalną. [...] Transcendentalna faktyczność jest istniejącym tu-podmiotem (Da-Sein), a samo wyrażenie ,ja jestem" stanowi filozoficzną abstrakcję i w istocie ma zawsze znaczenie ,ja jestem tu”. „Tu” jest przy tym określeniem transcendentalnym tylko wówczas, gdy wskazuje na zerowy punkt ciała, z którego podmiot doświadcza rzeczy [...]. W tym sensie owo "tu" rozumiane jako granica możliwego poznania, jest określeniem absolutnym. Mówiąc " ja jestem tu" wskazujemy na faktyczność transcendentalnej świadomości. Jest to absolutna konieczność tzn. nie można jej rozpatrywać w ramach opozycji fakt-istota. Absolut ma w sobie samym podstawę [...]. Fenomenologia kwestionując koncepcje ontologicznego podwojenia Ja sytuuje się ponad idealizmem i realizmem. Piotr Łaciak, Status podmiotowości w fenomenologii Husserla, „Fenomenologia” 2009, nr 7, s. 64-75. 
nej obiektywności świata. Do doświadczanego świata należą też obiekty określane jako „płynące z ducha”, które zgodnie ze swym sensem odsyłają do obcych podmiotów i ich aktywnie konstytuujących aktów intencjonalnych. Możemy więc mówić tu o uniwersalnej warstwie sensu, która promieniuje z innych podmiotów, co dopiero umożliwia istnienie dla mnie świata obiektywnego. Spełniając te apodyktycznie oczywiste akty wydobywania na jaw moich własnych zasobów, odsłaniam uniwersalne formy strukturalne, w których istnieję jako ego (formy bez, których nie mogę istnieć). W ten sposób ego obejmuje sobą uniwersum tego, co stanowi jego własność. Uniwersum, które można odsłonić przez źródłowe rozwinięcie ego sum. W obrębie tej źródłowej sfery świat poprzez redukcję do tego co moje własne, wyrasta na podłożu intencjonalnego fenomenu jako świat obiektywny. Wtedy konstytuuje się alter ego, czyli człowiek, którym nie jestem Ja sam, lecz jest to coś, co się w mojej monadzie odzwierciedla. Ego i alter ego zachodzą na siebie w momencie, kiedy zachodzą na siebie ich sensy przedmiotowe. Dzieje się tak, ponieważ "Inny odsyła w swym ukonstytuowanym sensie do mnie samego, Inny jest odzwierciedleniem mnie samego" ${ }^{\prime \prime 3}$. Fakt, że mogę uświadomić sobie jakieś inne Ja, wskazuje na to, że pośród różnych modi mojej świadomości są takie, które nie należą do mojej samowiedzy. Inny, mimo że jest mi obcy, to umożliwia konstytutywnie pojawienie się nowego, nieograniczonego obszaru tego, co obce. Wraz z taką konstytucją dokonuje się proces nadbudowywania sensu nad moim światem pierwotnego pochodzenia. W ten sposób konstytuuje się wspólnota monad, która konstytuuje we wspólnej intencjonalności jeden i ten sam świat. To transcendentalne My staje się więc właściwym podmiotem świata, ponieważ każde Ja jest wyposażone we wzajemnie sobie odpowiadające systemy konstytutywne. Oznacza to, że poszczególne systemy konstytucji realizują się harmonijnie w poszczególnych monadach. To transcendentalna intersubiektywność jest tym właściwym podmiotem będącym gwarantem wszelkiej konstytucji. Ja transcendentalne żyje bowiem we wszystkich potencjalnych i aktualnych przeżyciach jako Ja identyczne.

Sens przedmiotowy ma budowę warstwową tzn. wszelkie doświadczanie posiada akty przenoszenia sensu przedmiotowego na płaszczyznę nowej sytuacji. Podobnie jest w przypadku redukcji nad Ja transcendentalnym. "Zauważam również, że choć nie na sposób czegoś uchwyconego, byłem jednak czymś sobie samemu wstępnie danym, nieustannie wprzód danym jako coś obecnego w oryginale i naocznie"38. Tej nieustannej prezentacji sobie samemu towarzyszy nieograniczony horyzont własnych jeszcze nie odkrytych wewnętrznych własności. Każde doświadczenie pociąga za sobą kolejne doświadczenie potwier-

37 Edmund Husserl, ibidem, s. 137.

38 Edmund Husserl, ibidem, s. 149. 
dzające dane współ-prezentowanych horyzontów. Dlatego też każde spostrzeżenie zewnętrzne jest spostrzeżeniem transcendującym, ponieważ ustanawia w bycie coś więcej niż ono samo w danym momencie uobecnia. Inny pojawia się wtedy jako modyfikacja mojej jaźni. Dzieje się tak, ponieważ wraz z Innym jego Ja jest współ-prezentowane wraz z wszystkim, co stanowi jego własny świat $\mathbf{z n}$. w obrębie mojej monady konstytuuje się w trybie współ-prezentacji inna monada. Podobnie jak w sferze mojej żywej teraźniejszości, gdzie prezentowana jest moja własna przeszłość, która jest dana przez akty pamiętania. Tak samo jak moja przypominana przeszłość transcenduje moją żywą teraźniejszość jako jej modyfikacja, podobnie współ-prezentowane obce istnienie transcenduje moje własne.

Jak pokazuje analiza fenomenologiczna, zjawiska psychiczne posiadają swój własny styl syntetycznych powiązań oraz własny styl form, $\mathrm{w}$ jakich przebiegają. Formy te mogę zrozumieć, opierając się na moim własnym stylu, który jest mi empirycznie dany w jego przybliżonej typice. Każde przeniknięcie w wewnętrzną sferę Innego może skutkować wtedy aktami nowych możliwości zrozumienia danego aktu psychicznego, jak i nowym zrozumieniem mojego własnego świadomego życia $^{39}$. Odsłaniają się tu podobieństwa i różnice względem życia Innego. To z kolei prowadzi to uznania, że żyjemy we wspólnocie monad, która nie przejawia się jedynie $\mathrm{w}$ tym, że jest nam dany wspólny świat. Wszystkie systemy dane w akcie współ-prezentoiwania jako systemy Innego są tymi samymi, którymi Ja dysponuję. Posiadamy te same systemy przejawów noetyczno-noematycznych wraz ze wszystkimi możliwymi spostrzeżeniami. Według Husserla monada łączy się z drugą monadą poprzez systemy intencjonalne, co zakłada zrównanie mojego istnienia z istnieniem innych podmiotów. Jest to wyjątkowa więź, która transcendentalnie umożliwia istnienie świata ludzi i rzeczy. Husserl nazywa ten świat „światem życia" ${ }^{40}$. Jego istnienie tłumaczy też na przykładzie fenomenu kultury. Konstytucja każdego świata kultury podlega prawom konstytucji, tj. zakłada to, co pierwotnie i pochodnie ukonstytuowane we mnie. W ten sposób ukazuje nam się spodnia warstwa pojęcia świata, warstwa która pozostaje, gdy abstrahujemy od tego, co nazywamy obiektywnym światem $\mathrm{w}$ potocznym rozumieniu. $\mathrm{W}$ ciągle zmieniającym się

39 Według Rosiaka czystość absolutnej świadomości u Husserla nie oznacza jej oczyszczenia z tetycznych składowych zmysłowych przeżyć spostrzeżeniowych, lecz uzupełnienie ich o refleksyjną świadomość, że te tetyczne składowe aktów mają aktywny, a nie receptywny charakter. Marek Rosiak, Husserlowska koncepcja czystej świadomości- próba krytyki immanentnej, „Studia Philosophiae Christianae” 2008, nr 2, s. 78.

40 Lebenswelt jest pierwszym światem to intersubiektywny świat zawierający praktykę i komunikację przedzałożeń wszystkich nauk. Grzegorz Malinowski, Husserliana XXXIX: Die Lebenswelt, „Filo-Sofija” 2006, s. 125. 
świecie zmieniają się także ludzie jako osoby, przyjmując nowe własności habitualne ${ }^{41}$. W ten sposób z apodyktycznie danego ego wydobywa się transcendentalny sens świata jako nieustannie istniejący świat życia, którego istnienie określane jest przez istoty przeżyć mających swoje źródło w transcendentalnym Ja, a następnie w odsłaniającej się w nim intersubiektywności opierającej się na istotowych formach transcendentalnej motywacji i transcendentalnej konstytucji. Kiedy odsłaniamy ów aprioryczny styl uzyskujemy wyjaśnienie najwyższej rangi tj. poznanie absolutne. W ten sposób Husserl przedstawia nowe a priori, które związane jest z konstytucją której korelatem jest obiektywnie istniejący świat ${ }^{42}$. Świat, który konstytuuje się we wciąż nowych warstwach sensu w odpowiednio apriorycznym formalnym stylu. Ten rodzaj konstytucji jest ze sfery a priori, ponieważ realizujące się akty są rozwijane w ramach tego, co intencjonalnie zawarte $\mathrm{w}$ moim ego oraz $\mathrm{w}$ istotowych pochodnych mnie samego. Jest to nowa ontologia świata, w której wszelki obiektywny świat jest zakorzeniony $\mathrm{w}$ transcendentalnej subiektywności nadającej ukonstytuowany sens. Oznacza to, że wszystko co naturalnie dane, zostaje teraz $\mathrm{w}$ nowej pierwotności na nowo zbudowane i przestaje być czymś ostatecznie obowiązującym.

Trudno jest więc zaprzeczyć Husserlowi i powiedzieć, że czysta świadomość i transcendentalna intersubiektywność to tylko idee. Każdy z nas konstytuuje swój własny świat w odniesieniu do procesów konstytucji Innego. Zgodnie z monadologią każda monada wytycza sobą pewne uniwersum - pewien zamknięty świat monad. Fenomenologiczna transcendentalna redukcja na ego jako intencjonalne wydobywanie zasobów ujawniającego się transcendentalnego ego prowadzi do intuicyjnej ejdetyki, która daje możliwość zapanowania nad wszelkimi dającymi się pomyśleć możliwościami konstytutywnymi. Ten system a priori, który jest wrodzony Ja transcendentalnemu jest rozwinięciem uniwersalnego a priori transcendentalnej intersubiektywności. Absolutne poznanie jest zatem drogą uniwersalnego samopoznania, najpierw monadycznego, potem wspólnoty monad. Zarzut, jaki stawia Levinas Husserlowi o braku skuteczności metody fenomenologicznej w opisie

41 Habitualności obok asocjacji są drugą siłą pasywnej syntezy w teorii czystej świadomości Husserla. Wyznaczają one style poznawcze przedmiotów. Dzięki nim każdy przedmiot odsyła do swojego prawidła struktury, według którego może być dany innym odmianom świadomości w swojej typice. Chodzi tu o przewidziane typy własności jeszcze nie doświadczonych. Ja utożsamia się z własnościami habitualnymi, które są obecne w aktach zajmowania postawy. Wraz z tym podmiot doświadcza niestematyzowalne horyzonty tj. możliwość antycypowania przyszłych postaw. Marek Maciejczak, Rola stosunków aktywność-pasywność w husserlowskiej teorii świadomości, „Kwartalnik Filozoficzny” 2014, t. 42, z. 3, s. 37-39.

42 Piotr Łaciak, Kant i Husserl a problem ontologizacji i deformalizacji a priori, „Folia Philosophica" 2007, t. 25. 
relacji z Innym, nie ma do końca potwierdzenia. Pomimo że relacja z Innym nie daje się z góry określić (bo jest ciągle w toku tworzenia nowych istotowych powiązań), to mamy tu do czynienia z pewnym dającym się zidentyfikować typem nowej intencjonalności nie odnoszącej się już do świata. Choć ta nowa intencjonalność w obu przypadkach nie daje się stematyzować, to pozostaje jednak możliwość podążania za intuicją transcendentalnej konstytucji, która jest śladem absolutu w świecie.

\section{Bibliografia:}

Bańka J., Kategoria "teraz” w Husserla fenomenologii czasu i recentywizmie, „Folia Philosophica", t. 25, 2008.

Bęben D., Fink i jego dzieło, „Fenomenologia” 2009, nr 7.

Bruzina R., Edmund Husserl and Eugen Fink: Beginings and Ends in Phanomenology 1928-1938, Yale Uniwersity Press 2004.

Fink E., Sixth Cartesian Meditation, Indiana University Press 1995.

Gadacz T., Filozofia Boga w XX wieku, Kraków 2007.

Heidegger M., Ku rzeczy myślenia, Warszawa 1999.

Heidegger M., Bycie i czas, Warszawa 1994.

Heidegger M., Podstawowe problemy fenomenologii, Warszawa 2009.

Husserl E., Badania logiczne, Warszawa 2000.

Husserl E., Wykłady z wewnętrznej świadomości czasu, Warszawa 1989.

Ingarden R., Spór o istnienie świata, Warszawa 1961.

Ingarden R., Wstęp do fenomenologii Edmunda Husserla, Warszawa 1974.

Ingarden R., Z badań nad filozofia wspótczesna, Warszawa 1963.

Jeziorski M., O możliwości poznania u Husserla, „Edukacja Filozoficzna” 2008, vol. 45.

Judycki S., Intersubiektywność i czas, Lublin 1990.

Landgrebe L., Der Weg der Phänomenologie, Gütersloher Verlagshaus Mohn 1963.

Landgrebe L., Six Essays, Cornell University Press 1981.

Lauer Q., The triumph of subjectivity, Fordham University Press 1978.

Lawlor L., Derrida and Husserl, Indiana University Press 2002.

Levinas E., Bóg, śmierć i czas, Wydawnictwo Znak 2008.

Levinas E., O Bogu, który nawiedza myśl, Kraków 1994.

Levinas E., Całość i Nieskończoność, Warszawa 2014.

Levinas E., Całość i Nieskończoność, Warszawa 2014.

Levinas E., Istniejący i istnienie, Kraków 2006.

Łaciak P., Husserlowski model aprioryzmu: ontologizacja, deformalizacja i relatywizacja a priori, „Principia” 2007, t. 47/48.

Łaciak P., Kant i Husserl a problem ontologizacji i deformalizacji a priori, „Folia Philosophica" 2007, t. 25.

Łaciak P., Status podmiotowości w fenomenologii Husserla, „Fenomenologia” 2009, nr 7. 
Husserl E., Filozofia jako nauka ścisła, Warszawa 1992.

Husserl E., Idee czystej fenomenologii i fenomenologicznej filozofii, Warszawa 1975.

Husserl E., Kryzys nauk europejskich, Toruń 1999.

Husserl E., Medytacje Kartezjańskie, Warszawa 1982.

Malinowski. G „Husserliana XXXIX: Die Lebenswelt” Filo-Sofija 2006, s. 125.

Maciejczak M., Czasowość i jedność świadomości Kant-Husserl-Merleau Ponty, „Principia” 2007, t. 47/48, s. 132-133.

Maciejczak M., Rola stosunków aktywność-pasywność w husserlowskiej teorii świadomości, „Kwartalnik Filozoficzny”, t. 42, z. 3.

Migasiński J., Transcendencja Levinasa, „Filo-Sofija” 2006, nr 1.

Moustakas C., Fenomenologiczne metody badań, Białystok 2001.

Rosiak M., Husserlowaska koncepcja czystej świadomości - próba krytyki immanentnej, „Studia Philosophiae Christianae” 2009, nr 2.

Stein E., O zagadnieniu wczucia, Kraków 1988.

Stein E, Byt skończony a byt wieczny, Kraków 1995.

Stein E., Twierdza duchowa, Poznań 2006.

Tischner J., Ja transcendentalne w filozofii Edmunda Husserla, Kraków 1963.

Tymieniecka A.T., Życie w petni Logos, Poznań 2011.

Tymieniecka A.T., Logos and Life, book 2, Springer 1988.

Zahavi D., Fenomenologia Husserla, Kraków 2012.

\section{Streszczenie}

\section{Levinas i Husserl: transcendentalna intersubiektywność}

\section{Słowa kluczowe}

czysta świadomość; transcendentalna intersubiektywność; Ja transcendentalne; Absolut; redukcja epoche

Artykuł ten jest porównaniem koncepcji Innego u Levinasa i transcendentalnej intersubiektywności Husserla. W obu tych filozofiach relacje międzypodmiotowe odgrywają istotną rolę w identyfikacji transcendentalnej podstawy. Zarówno u Levinasa, jak i u Husserla, kontakt z Innym nie tylko otwiera nas na transcendencję, ale staje się warunkiem obiektywnej rzeczywistości. Tylko w transcendentalnej intersubiektywności przedmiot zostaje ukonstytuowany z mocą obowiązywania, która transcenduje podmiot. Oznacza to, że moja indywidualna intencjonalność zawiera a priori odniesienie do transcendentalnej intersubiektywności jako transcendentalnego obszaru konstytucji. To pokazuje, że nie tylko subiektywność ma swoje czasowe a priori, lecz rozwinięte subiektywne a priori odpowiada apriorycznej konstytucji genetycznej, która osadza się na tej pierwszej. Relacja z Innym to nowy wymiar świadomości, któremu dostępne jest to co absolutne. Tej niezwykłej relacji nie poznajemy inaczej niż poprzez urzeczywistnianie jej. Dlatego Absolut może się wydarzyć tylko poprzez Ja. 


\section{Summary}

\section{Levinas and Husserl: transcendental intersubjectivity}

\section{Keywords}

pure consciousness; transcendental intersubjectivity; transcendental I; Absolute; reduction of epoche

This article is a comparison of the concept of Other in works of Levinas with transcendental intersubjectivity in Husserl's works. In both of these philosophies relations between subjects have a significant role in the identification of the transcendental basis. In works of both Levinas and Husserl the contact with the Other not only opens us to transcendence, but also becomes a necessary condition of objective reality. Only through transcendental intersubjectivity an object is effectively constituted. This means that my individual intent includes a priori a reference to transcendental intersubjectivity as a transcendental area of constitution. This shows that not only the subjectivity has a time a priori, but developed subjective a priori corresponds with a priori genetic constitution which is based on the first one. Relation with Other is a new dimension of consciousness to which the absolute is available. We learn about this extraordinary relation through carrying it out. This is why the Absolute can happen only through I. 